Saudi Journal of Medicine

Abbreviated Key Title: Saudi J Med ISSN 2518-3389 (Print) |ISSN 2518-3397 (Online)

\title{
Study of Hematological Manifestations in HIV/AIDS and To Assess Their Correlation to Severity of Disease
}

\author{
Dhiraj Saini ${ }^{1}$, R P Agrawal ${ }^{2 *}$, B. L Meena ${ }^{3}$ \\ ${ }^{1}$ Resident Doctor, Department of General Medicine, S P Medical College, Bikaner, Rajasthan 334001, India \\ ${ }^{2}$ Senior Professor, Department of General Medicine, S P Medical College, Bikaner, Rajasthan 334001, India \\ ${ }^{3}$ Associate Professor, Department of General Medicine, S P Medical College, Bikaner, Rajasthan 334001, India
}

DOI: $10.36348 /$ SJM.2019.v04i12.001

| Received: 16.11.2019 | Accepted: 23.11.2019 | Published: 10.12.2019

*Corresponding author: R. P Agrawal

Abstract

Background: Haemotological abnormalities were common in patients with HIV infection. The common peripheral blood findings include anemia, thrombocytopenia, leucopenia or pancytopenia. These abnormalities may be attributable to the direct toxic effect of the virus on progenitor cells, ineffective hematopoiesis, opportunistic infections, immune mechanisms and drug reactions. Methods: It was a hospital based observational descriptive study conducted in department of medicine and ART centre at S P medical College Bikaner and associated group of hospital. Results: Leucopenia was seen in $46 \%$ cases and thrombocytopenia in $13 \%$ of cases. Hemoglobin level below $10 \mathrm{gm} \%$ was seen in $65 \%$. Mean HB level in HIV patients was $8.32 \pm 2.64 / \mathrm{dl}$, total WBC level was $4.27 \pm 0.54 \times 10^{3}$ cells $/ \mu 1$, Absolute lymphocytes level was $0.059 \pm 0.023 \times 10^{3}$ cells $/ \mu$ and platelet level was $13.29 \pm 6.76 \times 10^{3}$ cells $/ \mu \mathrm{L}$. Conclusion: Hematological abnormalities were common in patients with Acquired Immuno Deficiency Syndrome. Hemoglobin concentration, percentage of neutrophils and lymphocytes were significantly reduced.

Keywords: Acquired Immuno Deficiency Syndrome (AIDS), Hematological manifestations, Hemoglobin, Neutrophils, Lymphocytes.

Copyright @ 2019: This is an open-access article distributed under the terms of the Creative Commons Attribution license which permits unrestricted use, distribution, and reproduction in any medium for non-commercial use (NonCommercial, or CC-BY-NC) provided the original author and source are credited.

\section{INTRODUCTION}

The acquired immunodeficiency syndrome (AIDS), is a fatal illness caused by a retrovirus known as the human immunodeficiency virus that breaks down the body's immune system, progressively leads to AIDS. There are 2.47 million persons in India living with HIV; equivalent to approximately $0.36 \%$ of the adult population. The revised national estimate reflects the availability of improved data rather than a Substantial decrease in actual HIV prevalence in India. The transmission route is still predominantly sexual $(87.4 \%)$; other routes of transmission by order of proportion include prenatal $(4.7 \%)$, unsafe blood and blood products $(1.7 \%)$, infected needles and syringes $(1.8 \%)$ and unspecified routes of transmission [1].

Haemotological abnormalities were common in patients with HIV infection. The common peripheral blood findings include anemia, thrombocytopenia, leucopenia or pancytopenia. These abnormalities may be attributable to the direct toxic effect of the virus on progenitor cells, ineffective hematopoiesis, opportunistic infections, immune mechanisms and drug reactions [2]. Anemia was a very common finding in patients with HIV infection, particularly in individuals with more advanced HIV disease. HIV infection alone without other complicating illness may produce anemia in some patients. HIV not only causes low CD4 counts but is also associated with granulocytopenia, thrombocytopenia, loss of specific cytotoxic lymphocytes and antibody specific response [3].

\section{MATERIAL AND METHODS}

Study Design: It was a hospital based observational descriptive study.

Sample size: The sample size was 100 patients.

Sampling method: Connivance sampling.

\section{Inclusion Criteria}

1. The patients diagnosed with HIV-1 \&2 reactive by ELISA method (both symptomatic and asymptomatic)

2. Age $>18$ years. 


\section{Exclusion Criteria}

1. Patients with previously known hematological disorder prior to HIV infection.

2. Patients with hepatic disorders and renal disorders due to other causes was be excluded from the study.

\section{Data Collection}

The patients was evaluated according to predetermined and pretested proforma to record the details of history, physical examination and investigations.

\section{OBSERVATION}

Maximum $30 \%$ patients were belong to $41-50$ Yrs age group and only $1 \%$ patients were less than 20 Yrs. $80 \%$ patients were male and $20 \%$ were female.

Table-1: Hematological manifestations wise distribution of AIDS patients ( $n=100)$

\begin{tabular}{|l|l|l|}
\hline Hematological manifestations & No. of patients & Percentage \\
\hline Leucopenia & 46 & $46 \%$ \\
\hline Thrombocytopenia & 13 & $13 \%$ \\
\hline HB level below 10GM\% & 65 & $65 \%$ \\
\hline
\end{tabular}

Leucopenia was seen in $46 \%$ cases and thrombocytopenia in $13 \%$ of cases. Hemoglobin level below $10 \mathrm{gm} \%$ was seen in $65 \%$.

Table-2: Blood picture wise distribution of AIDS patients $(n=100)$

\begin{tabular}{|l|l|l|}
\hline Blood picture & No. of patients & Percentage \\
\hline Dimorphic & 6 & $6 \%$ \\
\hline Marcocytic & 13 & $13 \%$ \\
\hline Microcytic hypochrnomic & 12 & $12 \%$ \\
\hline Normocytic hypochromic & 51 & $51 \%$ \\
\hline Normocytic Normochromic & 18 & $18 \%$ \\
\hline
\end{tabular}

In this study $51 \%$ were normocytic hypochromic, $18 \%$ were Normocytic Normochromic, $13 \%$ patients were Microcytic hypochrnomic.

Table-3: Haematological parameters of HIV patients

\begin{tabular}{|l|l|l|}
\hline Haematological parameters & Mean & SD \\
\hline $\mathrm{HB}(\mathrm{gm} / \mathrm{dl})$ & 8.32 & 2.64 \\
\hline Total WBC $\left(\times 10^{3}\right.$ cells $\left./ \mu \mathrm{L}\right)$ & 4.27 & 0.54 \\
\hline Absolute lymphocytes $\left(\times 10^{3}\right.$ cells $\left./ \mu \mathrm{L}\right)$ & 0.059 & 0.023 \\
\hline Platelet $\left(\times 10^{3} / \mu \mathrm{l}\right)$ & 13.29 & 6.76 \\
\hline
\end{tabular}

Mean HB level in HIV patients was was $0.059 \pm 0.023 \times 10^{3}$ cells $/ \mu$ and platelet level was $8.32 \pm 2.64 / \mathrm{dl}$, total WBC level was $13.29 \pm 6.76 \times 10^{3}$ cells $/ \mu \mathrm{L}$. $4.27 \pm 0.54 \times 10^{3}$ cells $/ \mu 1$, Absolute lymphocytes level

Table-4: Association between Hematological manifestations and severityof AIDS patients (n=100)

\begin{tabular}{|l|l|l|l|}
\hline Hematological manifestations & CD4 count $<\mathbf{2 0 0 \mathbf { m m } ^ { 3 }}$ & $\mathbf{C D 4}$ count $\mathbf{> 2 0 0} \mathbf{~ m m}^{\mathbf{3}}$ & P-value \\
\hline Leucopenia & 13 & 23 & $>0.05$ \\
\hline Thrombocytopenia & 3 & 10 & $<0.05$ \\
\hline Hb level below 10gm\% & 18 & 47 & $>0.05$ \\
\hline
\end{tabular}

The association between severity of HIV infection and was Hematological manifestations significant.

\section{DISCUSSION}

In our study, maximum $30 \%$ patients were belong to $41-50$ Yrs age group and only $1 \%$ patients were less than 20 Yrs.

Studies done by Sitalakshmi et al., [4] was observed that maximum numbers of patients belonged to 41-50years of age group. Chanarat et al., [5] also reported similar age group distribution.

Bartholomew Okecuhukwu Ibeh et al., [4] was observed the ages of the $\mathrm{HIV}^{+}$HAART group $36 \pm 10$ Yrs.

Males were more commonly affected by the disease $(80 \%)$ than female $(20 \%)$ in our study. 
Sitalakshmi et al., [5] was observed that male $(60 \%)$ and female Was (40\%).

Chanarat et al., [6] was also observed that male was more effected than female.

Leucopenia was seen in $46 \%$ cases and thrombocytopenia in $13 \%$ of cases. Hemoglobin level below $10 \mathrm{gm} \%$ was seen in $65 \%$ in our study.

In the study by Chanarat et al., [5] was seen in $51 \%$ cases and thrombocytopenia in $16 \%$ of cases.

Leucopenia was seen in $30 \%$ cases and thrombocytopenia in $21 \%$ of cases. Hemoglobin concentration, percentage of neutrophils and lymphocytes were significantly reduced in study conducted by Ramakrishna et al., [4].

In our study $51 \%$ were normocytic hypochromic, $18 \%$ were Normocytic Normochromic, $13 \%$ patients were Microcytic hypochrnomic.

Swati Kathuria et al., [5] was observed the prevalence of anemia, leucopenia and thrombocytopenia was $46 \%, 25 \%$ and $24 \%$ respectively. The incidence of these abnormalities increased in patients having lower CD4 counts. Anemia was more common in untreated group whereas patients on ART had a higher incidence of leucopenia.

Most common type of blood picture was normocytic normochromic blood picture seen in studies, Bodey et al., [7] Moore et al., [8].

Mean HB level in HIV patients was $8.32 \pm 2.64 / \mathrm{dl}$, total WBC level was $4.27 \pm 0.54 \times 10^{3}$ cells $/ \mu 1$, Absolute lymphocytes level was $0.059 \pm 0.023 \times 10^{3}$ cells $/ \mu$ and platelet level was $13.29 \pm 6.76 \times 10^{3}$ cells $/ \mu \mathrm{L}$ in our study and in the study by Chanarat et al., [6] was seen same result.

\section{CONCLUSIONS}

Hematological abnormalities were common in patients with Acquired Immuno Deficiency Syndrome.
Hemoglobin concentration, percentage of neutrophils and lymphocytes were significantly reduced.

\section{REFERENCES}

1. Sitalakshmi, S., Srikrishna, A., \& Damodar, P. (2003). Haematological changes in HIV infection. Indian journal of pathology \& microbiology, 46(2), 180-183.

2. Chanarat, N., Chanarat, P., Viratsethasin, K., Suttajit, M., \& Chiewsilp, D. (2001). Biochemical and hematological manifestations of HIV/AIDS in Chiang Mai, Thailand. Southeast Asian journal of tropical medicine and public health, 32(3), 500503.

3. Ahasan, M. M., Billah, M. M., Hasan, M. M., Islam, K. M. D., \& Shilpi, J. A. (2004). Transmission, biochemical manifestation and CD4+ cell count of HIV: A review. Pakistan Journal of Biological Sciences, 7(2), 292-300.

4. Ramakrishna, G., Venkata, V. G. R. S., \& Chaitanya, G. (2015). Correlation of hematological and biochemical parameters to severity of disease in acquired immuno deficiency syndrome. IMTU Medical Journal, 6(1), 12-14.

5. Swati, K. (2016). Hematological Manifestations in HIV Infected Patients and Correlation with CD4 Counts and Anti Retroviral Therapy. IJCMR; 3(2):2453-6.

6. Chanarat, N., Chanarat, P., Viratsethasin, K., Suttajit, M., \& Chiewsilp, D. (2001). Biochemical and hematological manifestations of HIV/AIDS in Chiang Mai, Thailand. Southeast Asian journal of tropical medicine and public health, 32(3), 500503.

7. Bodey, G. P., Buckley, M., Sathe, Y., \& Freireich, E. J. (1966). Quantitative relationships between circulating leukocytes and infection in patients with acute leukemia. Annals of internal medicine, 64(2), 328-340.

8. Moore, R. D., \& Forney, D. (2002). Anemia in HIV-infected patients receiving highly active antiretroviral therapy. Journal of acquired immune deficiency syndromes (1999), 29(1), 54-57. 